\title{
Effect of Heat Treatment and Particle Size on the Crystalline Properties of Wood Cellulose ${ }^{1}$
}

\author{
Ah-ran $\mathrm{Kim}^{2} \cdot$ Nam-Hun Kim $\mathbb{D}^{2, \dagger}$
}

\begin{abstract}
This study was carried out to investigate the effect of heat-treatment and particle size on the crystalline properties of the wood cellulose. The color of wood flours was changed from light yellow in control sample to dark yellow or deep brown by heat treatment at $100^{\circ} \mathrm{C}$ to $200^{\circ} \mathrm{C}$. Relative crystallinity of the heat treated wood cellulose decreased with decreasing particle size from wood chips to 200 mesh, and there was little change in the crystal width. As the temperature was increased, relative crystallinity of the wood increased and crystal width was not changed. As a result of the FT-IR analysis, it was confirmed that the peaks were gradually decreased at $-\mathrm{OH}$ elongation as the heat-treated temperature was increased. The lignin C-H bending of $1425 \mathrm{~cm}^{-1}$ and the hemicellulose $\mathrm{C}-\mathrm{H}$ bending of $1370 \mathrm{~cm}^{-1}$ did not change with the increase of the heat treatment temperature. In addition, it was revealed that C-C stretching of carbohydrate near $1031 \mathrm{~cm}^{-1}$ decreased with increasing heat treatment temperature. Consequently, it is suggested that particle size and heat treatment affected the crystalline properties of wood cellulose.
\end{abstract}

Keywords: Paulownia tomentosa, particle size, heat-treatment, relative crystallinity, wood flours

\section{INTRODUCTION}

As the demand for environmental preservation increases worldwide, environmentally friendly, heattreated, and weatherproof wood materials that can be used to address shortages in resources and energy without producing toxic residues have drawn much attention (Sandberg et al., 2013, 2015; Esteves et al., 2009). Heat treatment of wood is a type of polishing method that produces dimensional stability and increases weather resistance by controlling the wood's thermal degradation and changing its chemical composition (Kim, 2016). Several studies have reported heat-induced changes in wood properties (Čermák and Dejmal, 2013; Tu et al., 2014; Park et al., 2015; Chung et al., 2016; Gong et al., 2016; Hidayat et al., 2016; Lee and Kim, 2016; Jang et al., 2017; Hidayat et al., 2016; Won et al., 2017; Park et al., 2018).

Heat treating wood eliminates wood-extract components, degrades hemicellulose, and causes changes in cellulose and lignin. It is speculated that heat-induced changes in wood color result from a reduction in hemicellulose (Kim, 2016; Garrote et al., 1999). Heat treatment partially degrades the hemicellulose within the wood, induces changes in the composition of wood extracts, and causes the formation of new chemical

${ }^{1}$ Date Received January 24, 2019, Date Accepted May 8, 2019

2 Department of Forest Biomaterials Engineering, College of Forest and Environmental Sciences, Kangwon National University, Chuncheon 24341, Republic of Korea

† Corresponding author: Nam-Hun Kim (e-mail: kimnh@kangwon.ac.kr, ORCID: 0000-0002-4416-0554) 
bonds (Yun et al., 2015). Acetyl groups, which are thermally unstable, give rise to acetic acids. These acids have a significant influence on the thermal degradation of hemicellulose (Výbohová et al., 2018). Changes in the amount and structure of hemicellulose reduce bending and tensile strengths, and cellulose degradation is considered to be a major cause of reduced tensile strength (Boonstra et al., 2007). Martinka et al. (2014) have reported that heat-treated spruce is safer than non-heat-treated spruce after a fire resulted from the maximum reduction in the heat release rate. Wood generally darkens when heated. This color change is typically observed after exposure to temperatures $>70^{\circ} \mathrm{C}$, and the color becomes darker over time and as the temperature and humidity increase (Stenudd, 2004). Heat treatment increases the crystallinity of wood cellulose (Bhuiyan et al., 2000), and it has been reported that the relative crystallinity of wood increases when heat is increased to $80-200^{\circ} \mathrm{C}$ (Wang et al., 2015). Akgül et al. (2007) have reported that the relative crystallinity of pine and fir increases following heat exposure for a specific period of time, and they attributed such an increase to the changes in the monoclinic structure with a relatively high composition ratio into a triclinic structure during treatment.

One study has reported that the relative crystallinity or crystal size decreases as the size of the wood particle decreases, and that ball milling causes crystalline regions to turn into noncrystalline regions (Isogai, 2008). There has also been growing interest in woodbased nanocellulose, and the process of disk milling reduces particle size and is essential for the production of nanocellulose. Various domestic studies have been conducted on wood micronization as a step in nanocellulose production (Lee et al., 2010; Jang et al., 2012, 2013, 2014; Han et al., 2017; Seo et al., 2018).

Thus, in our study, we used heat treatment, which enhances the physical properties of wood, to experiment with cellulose, the largest constituent of wood. In addition, we investigated the effects of wood flour particle size and heat treatment on the crystalline properties of wood cellulose with the ultimate aim of providing basic data on the patterns related to cellulose crystals during treatment.

\section{MATERIALS and METHODS}

\subsection{Testing materials}

Branches of wild Paulownia tomentosa grown in the experimental forest of Kangwon National University, Gangwon-do, South Korea, were used as testing materials in this study.

\subsection{Experimental method}

\subsubsection{Wood flour production}

The $P$. tomentosa branches were subjected to a first round of grinding using Hammer mill (Hammer Mill Vertica DFZK [GM], Bühler GmbH, Braunschweig, Germany) available in a workshop at the College of Forest and Environmental Sciences, Kangwon National University (Fig. 1). The size of the resulting wood flour particles was made uniform using a continuous grinder (KOREAMEDI CO., LTD. Korea) (Fig. 1). The wood flour was then divided according to size (40, 60 100, or 200 mesh).
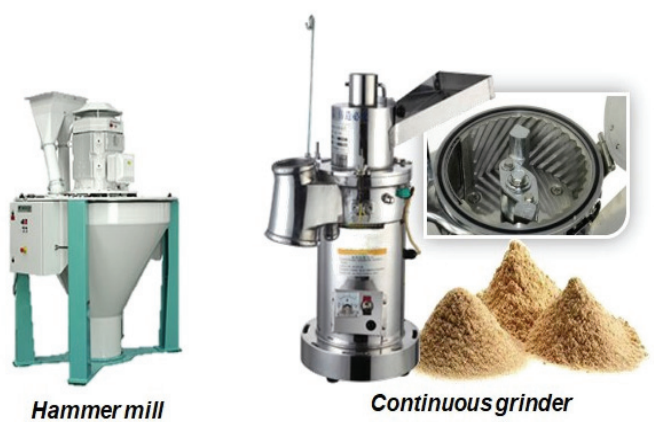

Fig. 1. Hammer mill ${ }^{1}$ and continuous grinder ${ }^{2}$ used to prepare the wood.

Sources: ${ }^{1}$ (Hammer Mill Vertica DFZK [GM], Bühler GmbH Germany); ${ }^{2}$ (KOREAMEDI CO., LTD. Korea). 
Table 1. Weight loss of wood flours under different conditions

\begin{tabular}{|c|c|c|c|c|}
\hline $\begin{array}{l}\text { Nitrogen } \\
\text { gas }\end{array}$ & $\begin{array}{c}\text { Particle } \\
\text { size(mesh) }\end{array}$ & Control & $100^{\circ} \mathrm{C}$ & $200^{\circ} \mathrm{C}$ \\
\hline \multirow{4}{*}{ With } & 40mesh & \multirow{8}{*}{$1.5 \mathrm{~g}$} & $\begin{array}{c}1.47 \mathrm{~g} \pm 0.03 \\
(-2 \%)\end{array}$ & $\begin{array}{c}1.3 g \pm 0.03 \\
(-13.3 \%)\end{array}$ \\
\hline & 60mesh & & $\begin{array}{c}1.46 \mathrm{~g} \pm 0.03 \\
(-2.6 \%)\end{array}$ & $\begin{array}{c}1.29 \mathrm{~g} \pm 0.03 \\
(-14 \%)\end{array}$ \\
\hline & 100mesh & & $\begin{array}{c}1.46 \mathrm{~g} \pm 0.04 \\
(-2.6 \%)\end{array}$ & $\begin{array}{c}1.29 \mathrm{~g} \pm 0.07 \\
(-14 \%)\end{array}$ \\
\hline & 200mesh & & $\begin{array}{c}1.41 g \pm 0.015 \\
(-6 \%)\end{array}$ & $\begin{array}{c}1.27 \mathrm{~g} \pm 0.06 \\
(-15.3 \%)\end{array}$ \\
\hline \multirow{4}{*}{ Without } & 40mesh & & $\begin{array}{c}1.43 g \pm 0.02 \\
(-4.6 \%)\end{array}$ & $\begin{array}{c}1.26 g \pm 0.01 \\
(-16 \%)\end{array}$ \\
\hline & 60mesh & & $\begin{array}{c}1.42 \mathrm{~g} \pm 0.01 \\
(-5.3 \%)\end{array}$ & $\begin{array}{c}1.25 g \pm 0.02 \\
(-16.6 \%)\end{array}$ \\
\hline & 100mesh & & $\begin{array}{c}1.41 \mathrm{~g} \pm 0.02 \\
(-6 \%)\end{array}$ & $\begin{array}{c}1.22 \mathrm{~g} \pm 0.02 \\
(-18.6 \%)\end{array}$ \\
\hline & 200mesh & & $\begin{array}{c}1.39 g \pm 0.01 \\
(-7.3 \%)\end{array}$ & $\begin{array}{c}1.19 g \pm 0.01 \\
(-20.6 \%)\end{array}$ \\
\hline
\end{tabular}

\subsubsection{Heat treatment}

An electric furnace available at the workshop was used to increase the temperature by $6^{\circ} \mathrm{C} / \mathrm{min}$. The wood flour was treated by heating at $100^{\circ} \mathrm{C}$ and $200^{\circ} \mathrm{C}$ for 30 min. During this process, mass reduction rates were compared between the specimens into which nitrogen gas was injected and those into which nitrogen gas was not injected. No significant difference was observed in the mass reduction rates of the two groups; therefore, the heat-treated specimens into which nitrogen gas was not injected were used (Table 1). The observed mass reduction appeared to have been caused by the reduction in the amount of extract components and volatile matter resulting from the heat treatment.

\subsubsection{Morphological characteristics}

The Nikon ECLIPSE, E600 optical microscope and the IMT i-Solution Lite image analysis program (https://www.martinmicroscope.com/imt-i-solution-lite -image-acquisition-and-measuring-software) were used to examine the wood particles in each wood flour group.

\subsubsection{Analysis of the crystalline properties of cellulose}

The DMAX2100V X-ray diffractometer (Rigaku Corp., Tokyo, Japan) was used to obtain the X-ray diffraction intensity curve of the wood flour specimens in each group at $40 \mathrm{kV}$ and $30 \mathrm{~mA}$. The Segal method (Segal et al., 1959) and the Scherrer equation (Scherrer, 1918) were used to calculate the relative crystallinity and crystal width.

Relative crystallinity determined using the Segal method and the following equation:

$$
\text { Cr. }(\%)=\frac{I_{200}-I_{a m}}{I_{200}} \times 100
$$

$I_{200}$ : Diffraction intensity of $(200)\left(2 \theta=22.8^{\circ}\right)$

$I_{a m}$ : Diffraction intensity of noncrystalline portion $\left(2 \theta=18^{\circ}\right)$

Crystal width determined using the Scherrer equation

$$
L(h k l)=\frac{K \cdot \lambda}{\beta \cdot \cos \theta}
$$

L : Crystal width, K: Scherrer constant, 0.9

$\lambda:$ X-ray wavelength $(\lambda=0.1542 \mathrm{~nm})$

$\beta$ : Half-width (radian), $\theta$ : Bragg angle

\subsubsection{Analyses of chemical components}

A Fourier-transform infrared spectroscopy (FTIR) spectrometer (PerkinElmer Inc., Waltham, MA, USA) at the laboratory center of Kangwon National University was used to perform attenuated total reflection spectroscopy with ranges of $400-4000 \mathrm{~cm}^{-1}$ to analyze changes in the chemical composition in the wood specimens after heat treatment. Non-heat-treated wood flour and 100-mesh wood flour created from the branches of $P$. tomentosa treated at $100^{\circ} \mathrm{C}$ and $200^{\circ} \mathrm{C}$ were used in the analyses. 


\section{RESULTS and DISCUSSION}

\subsection{Gross color changes in heat-treated wood flour}

Fig. 2 shows the appearance of the cellulose from the wood specimens of varying particle sizes treated at varying temperatures. The non-heat-treated wood flour was initially light brown and turned dark yellow to deep brown following heat treatment.

\subsection{Morphological properties of heat-treated wood flour}

Fig. 3 are images wood flour specimens of varying particle sizes treated at varying temperatures as observed under an optical microscope. The specimens turned dark brown as the temperature increased. Garotte et al. (1999) have reported that heat-induced changes in wood color are a result of a reduction in hemicellulose. Výbohová et al. (2018), who have studied heat-treated wood using ash trees, have reported that acidification begins at $160^{\circ} \mathrm{C}$, producing carbonyl and carboxyl groups, and the amount of lignin increases beginning at $180^{\circ} \mathrm{C}$, which contributes to color changes.

\subsection{Crystalline properties of heat-treated wood cellulose}

Fig. 4 shows the X-ray diffraction intensity curves of the wood flour of varying particle sizes that reflect the typical structure of cellulose I. Peaks tended to decrease on the (1 $\overline{1} 0)$, (110), and (200) planes as particle size decreased. Table 2 shows the relative crystallinity and crystal width based on the X-ray diffraction intensity curve. Wood chips had the highest relative crystallinity; whereas, the 200-mesh specimen had the lowest. The specimen treated at $100^{\circ} \mathrm{C}$ had higher relative crystallinity than the control specimen, and that treated at $200^{\circ} \mathrm{C}$ had higher relative crystallinity than that treated at $100^{\circ} \mathrm{C}$. It was clearly observed that relative crystallinity decreased as the size of the wood flour particles decreased, and that it increased as the heattreatment temperature increased, with nearly no changes in the width of the crystals.

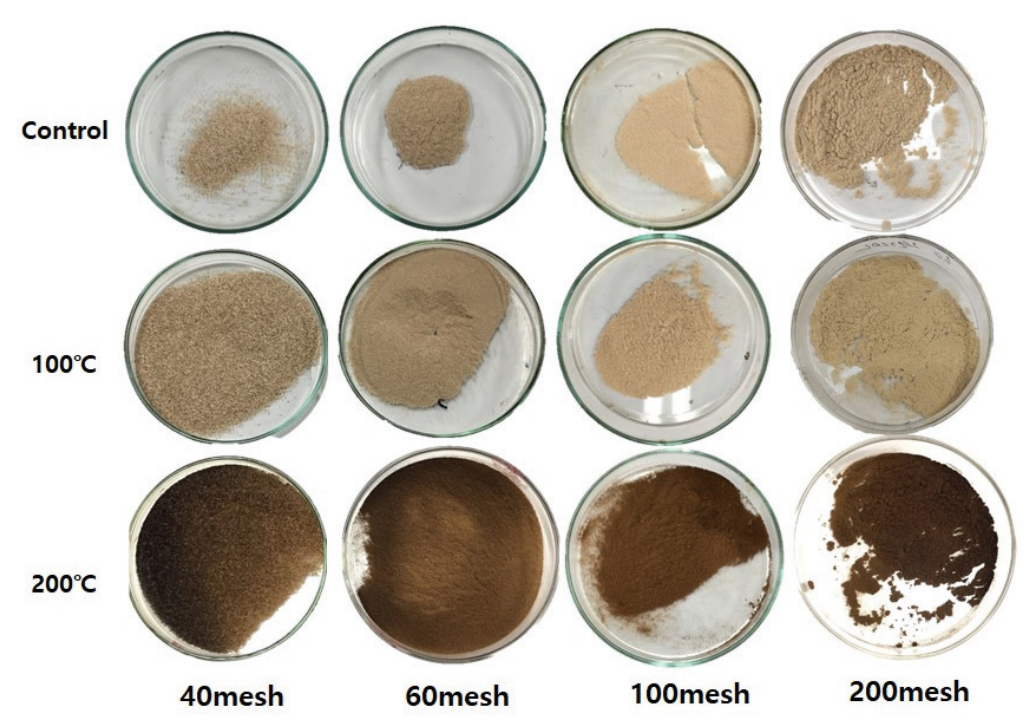

Fig. 2. Appearance of wood flours treated at different temperatures. 


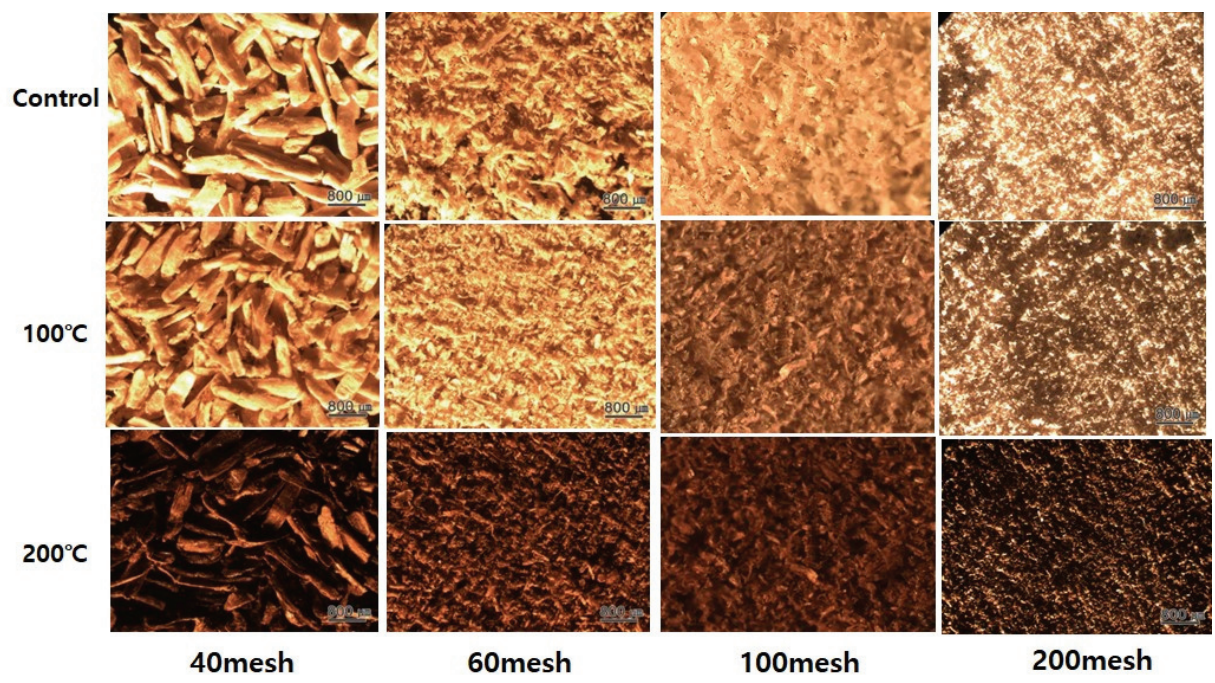

Fig. 3. Micrographs of heat-treated wood flours at different temperatures.
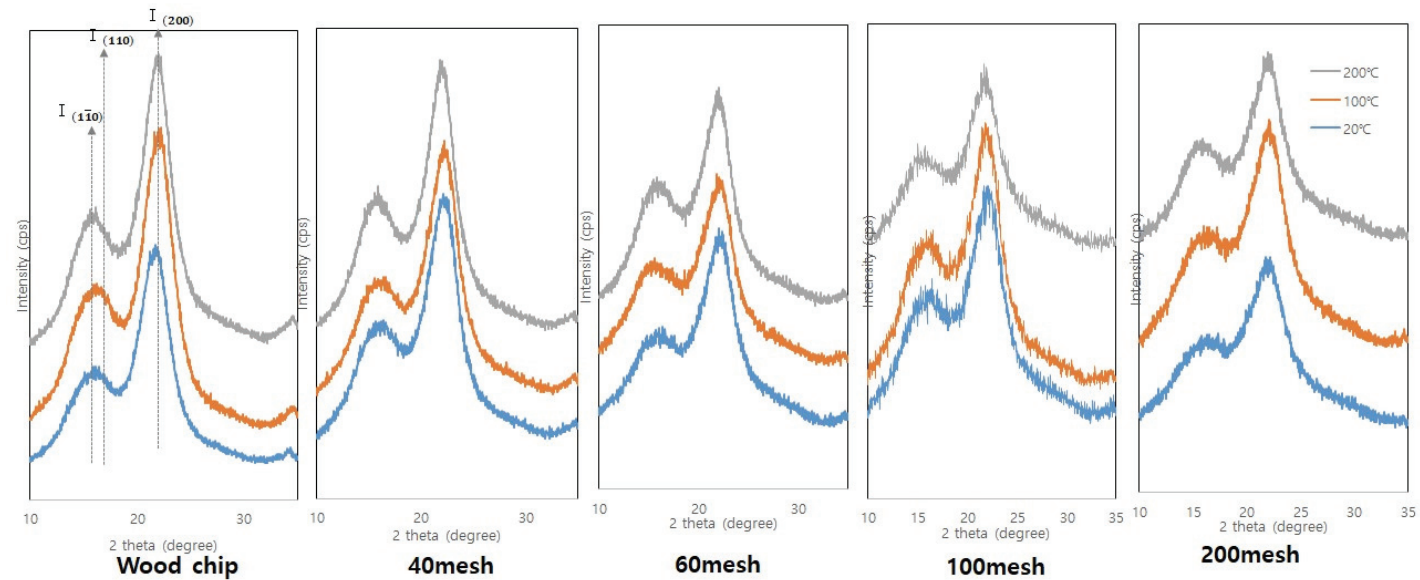

Fig. 4. X-ray diffraction patterns of heat-treated wood samples of different sizes.

Bhuiyan et al. (2000) have reported that heat treatment considerably increases the crystallinity of wood cellulose in spruce and beech trees. Wang et al. (2015) have reported that the relative crystallinity of eucalyptus flour increases when the heat treatment temperature increases from $80^{\circ} \mathrm{C}$ to $200^{\circ} \mathrm{C}$. Kim et al. (2018) have reported that heat treatment increases the relative crystallinity in Paulownia trees. The results of our study are consistent with those of these earlier studies. In addition, Akgül et al. (2007) have reported that the duration of heat treatment, in addition to the temperature used, significantly affects the relative crystallinity in the wood. On the other hand, Yun et al. (2015) have reported results that conflict with these findings stating that no clear changes were observed in the crystalline region in eucalyptus wood following heat treatment, but that crystal length and width increased as temperature increased. Additional studies 
Table 2. Effect of heat treatment on the crystalline properties of wood samples of different sizes

\begin{tabular}{ccc}
\hline Samples & $\begin{array}{c}\text { Relative } \\
\text { crystallinity (\%) }\end{array}$ & $\begin{array}{c}\text { Crystallite } \\
\text { width (nm) }\end{array}$ \\
\hline \hline Control (wood chip) & 52.4 & 2.36 \\
$100^{\circ} \mathrm{C}$ (wood chip) & 56.2 & 2.64 \\
$200^{\circ} \mathrm{C}$ (wood chip) & 57.5 & 2.59 \\
$\mathrm{Control}$ (40mesh) & 49.3 & 2.70 \\
$100^{\circ} \mathrm{C}$ (40mesh) & 51.8 & 2.96 \\
$200^{\circ} \mathrm{C}$ (40mesh) & 55.9 & 2.97 \\
$\mathrm{Control}(60 \mathrm{mesh})$ & 44.3 & 2.44 \\
$100^{\circ} \mathrm{C}$ (60mesh) & 50.9 & 2.61 \\
$200^{\circ} \mathrm{C}$ (60mesh) & 51.8 & 2.96 \\
$\mathrm{Control}$ (100mesh) & 39.3 & 2.41 \\
$100^{\circ} \mathrm{C}$ (100mesh) & 40.4 & 2.47 \\
$200^{\circ} \mathrm{C}$ (100mesh) & 42.1 & 2.54 \\
$\mathrm{Control}$ (200mesh) & 37.3 & 2.21 \\
$100^{\circ} \mathrm{C}$ (200mesh) & 38.8 & 2.56 \\
$200^{\circ} \mathrm{C}$ (200mesh) & 42.4 & 2.52 \\
\hline
\end{tabular}

on the effect of heat treatment on crystal length and width are needed. The increase in the relative crystallinity corresponding to a temperature increase appears to positively affect the crystalline properties in the wood because heat treatment reduces the extract components and volatile matter, thereby increasing wood strength, and destroys the noncrystalline regions to increase the ratio of the crystalline regions.

\subsection{Analyses of chemical components}

An FT-IR analysis was conducted to study heatinduced changes in the chemical composition of the wood specimens. The FT-IR spectrum of the non-heattreated specimens and the specimens treated at $100^{\circ} \mathrm{C}$ and $200^{\circ} \mathrm{C}$ are shown in Fig. 5. Table 3 summarizes the results of the spectrum shown in Fig. 5, and Table 4 provides the results from the other referenced studies (Bodirlau et al., 2009; Dai et al., 2011; Wang et al., 2012). Peaks were observed for -OH elongation at 3339 $\mathrm{cm}^{-1}, \mathrm{C}-\mathrm{H}$ vibration for the surface wax at $2917 \mathrm{~cm}^{-1}$,

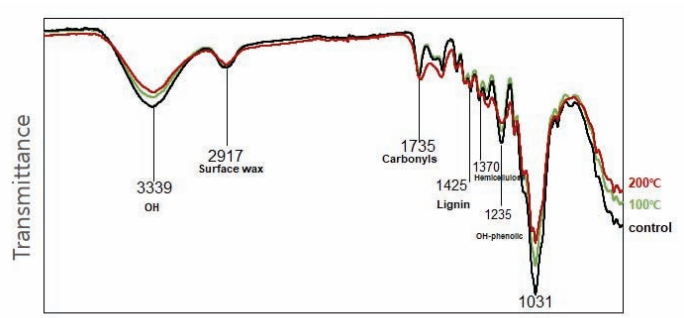

Wavenumber $\left(\mathrm{cm}^{-1}\right)$

Fig. 5. Fourier-transform infrared spectroscopy (FTIR) spectra of 100-mesh heat-treated wood flours at different temperatures.

Table 3. Assignment of the infrared bands to functional groups in wood

\begin{tabular}{ccc}
\hline Bond type & Peak $(\mathrm{cm}-1)$ & Remark \\
\hline -OH stretching & 3339.50 & \\
C-H vibration & 2917.12 & Surface wax \\
C=O stretching & 1735.34 & Carbonyls \\
C-H stretching & 1425.07 & Lignin \\
C-H bending & 1370.84 & Hemicellulose \\
O-H phenolic & 1235.88 & \\
C-C stretching & 1031 & Carbohydrate \\
\hline
\end{tabular}

Table 4. Assignment of the infrared bands to functional groups in wood (Bodirlau and Teaca., 2009; Dai and Fan, 2011; Wang et al., 2012).

\begin{tabular}{|c|c|}
\hline Band position $\left(\mathrm{cm}^{-1}\right)$ & Functional group \\
\hline $3450-3400$ & O-H group \\
\hline $2930-2910$ & $\begin{array}{l}\text { C-H methyl and methylene } \\
\text { groups, surface wax }\end{array}$ \\
\hline $1740-1730$ & $\mathrm{C}=\mathrm{O}$ carbonyls \\
\hline $1640-1618$ & $\mathrm{C}=\mathrm{C}$ alkene \\
\hline $1515-1504$ & $\mathrm{C}=\mathrm{C}$ aromatic \\
\hline $1462-1425$ & CH2 cellulose, lignin \\
\hline $1384-1346$ & C-H cellulose, hemicellulose \\
\hline $1260-1234$ & $\mathrm{O}-\mathrm{H}$ phenolic \\
\hline $1170-1153$ & $\begin{array}{l}\mathrm{O}-\mathrm{H} \text { alcohols(primary and } \\
\text { secondary) and aliphatic ethers }\end{array}$ \\
\hline $1046-1018$ & $\begin{array}{l}\text { C-C, C-OH, C-H ring and side } \\
\text { group vibrations }\end{array}$ \\
\hline 910 & $\mathrm{C}=\mathrm{C}$ alkenes \\
\hline
\end{tabular}


$\mathrm{C}=\mathrm{O}$ stretching of carbonyl groups at $1735 \mathrm{~cm}^{-1}, \mathrm{C}-\mathrm{H}$ bending of lignin at $1425 \mathrm{~cm}^{-1}$, C-H bending of hemicellulose at $1370 \mathrm{~cm}^{-1}$, OH-phenolic stretching at $1235 \mathrm{~cm}^{-1}$, and C-C stretching of carbohydrates at $\sim 1031$ $\mathrm{cm}^{-1}$.

The peaks at $3339 \mathrm{~cm}^{-1}$ for $-\mathrm{OH}$ elongation, at 1235 $\mathrm{cm}^{-1}$ for OH-phenolic stretching, and at $1031 \mathrm{~cm}^{-1}$ for C-C stretching of carbohydrates decreased as the temperature increased. This might be the effect of dehydration resulting from the reduction in hydroxyl groups caused by heat treatment as well as the reduction in the carbohydrates within the wood specimens. No evident change was observed for the peaks at 1735 $\mathrm{cm}^{-1}$ for $\mathrm{C}=\mathrm{O}$ stretching of carbonyl groups, which conflicts with the results reported by Výbohová et al. (2018). The lack of change might be a result of the relatively wide ranges in temperatures used in the experiment, which might compromise the precision of the results. No evident peak changes were observed for $\mathrm{C}-\mathrm{H}$ bending in lignin and $\mathrm{C}-\mathrm{H}$ bending in hemicellulose at $1370 \mathrm{~cm}^{-1}$. Contrary to our expectations, little change in hemicellulose and lignin was observed.

\section{CONCLUSION}

The results of our analysis of the crystalline properties of wood cellulose at varying particle sizes and heat-treatment temperatures showed several changes in the properties based on these two factors. With increases in temperatures from $100^{\circ} \mathrm{C}$ to $200^{\circ} \mathrm{C}$, the wood flour turned from light yellow to dark yellow or deep brown. In addition, the relative crystallinity in the wood increased as the temperature increased with no changes in crystal width. As the size of the wood particles decreased, the relative crystallinity tended to decrease as well with nearly no change in crystal width. Finally, FT-IR analyses showed peaks at $3339 \mathrm{~cm}^{-1}$ for $-\mathrm{OH}$ elongation, $2917 \mathrm{~cm}^{-1}$ for C-H vibration on the surface wax, $1735 \mathrm{~cm}^{-1}$ for $\mathrm{C}=\mathrm{O}$ stretching of carbonyl groups, $1425 \mathrm{~cm}^{-1}$ for $\mathrm{C}-\mathrm{H}$ bending of lignin, $1370 \mathrm{~cm}^{-1}$ for C-H bending of hemicellulose, $1235 \mathrm{~cm}^{-1}$ for $\mathrm{OH}-$ phenolic stretching, and $\sim 1031 \mathrm{~cm}^{-1}$ for C-C stretching of carbohydrates.

\section{ACKNOWLEDGMENT}

This research was supported by Basic Science Research Program through the National Research Foundation of Korea (NRF) funded by the Ministry of Education (No. NRF-2016R1D1A1B01008339).

\section{REFERENCES}

Akgül, M., Gümüşkaya, E., Korkut, S. 2007. Crystalline structure of heat-treated Scots pine [Pinus sylvestris L.] and Uludağ fir [Abies nordmanniana (Stev.) subsp. bornmuelleriana (Mattf.)] wood. Wood Science and Technology 41(3): 281.

Bhuiyan, M.T.R., Hirai, N., Sobue, N. 2000. Changes of crystallinity in wood cellulose by heat treatment under dried and moist conditions. Journal of Wood Science 46(6): 431-436.

Boonstra, M.J., Van Acker, J., Kegel, E., Stevens, M. 2007. Optimisation of a two-stage heat treatment process: durability aspects. Wood Science and Technology 41(1): 31-57.

Bodirlau, R., Teaca, C.A. 2009. Fourier transform infrared spectroscopy and thermal analysis of lignocellulose fillers treated with organic anhydrides. Romanian Journal of Physics 54(1-2): 93-104.

Chung, H., Han, Y., Park, J.H., Chang, Y.S., Park, Y., Yang, S.Y., Yeo, H. 2016. A Study on Dimensional Stability and Thermal Performance of Superheated Steam Treated and Thermal Compressed Wood. Journal of the Korean Wood Science and Technology 44(2): 184-190. 
Čermák, P., Dejmal, A. 2013. The effect of heat and ammonia treatment on colour response of oak wood (Quercus robur) and comparison of some physical and mechanical properties. Maderas. Ciencia y tecnología 15(3): 375-389.

Dai, D., Fan, M. 2011. Investigation of the dislocation of natural fibres by Fourier-transform infrared spectroscopy. Vibrational Spectroscopy, 55(2): 300-306.

Esteves, B. and Pereira, H. 2008. Wood modification by heat treatment: A review. BioResources 4(1): 370-404.

Fehér, S., Komán, S., Börcsök, Z., Róbert, T. 2014. Modification of hardwood veneers by heat treatment for enhanced colors. BioResources 9(2): 3456-3465.

Garrote, G., Dominguez, H., Parajo, J.C. 1999. Hydrothermal processing of lignocellulosic materials. European Journal of Wood and Wood Products 57(3): 191-202.

Gong, S.H., Ahn, B.J., Lee, S.M., Lee, J.J., Lee, Y.K., Lee, W.J. 2016. Thermal Degradation Behavior of Biomass Depending on Torrefaction Temperatures and Heating Rates. Journal of the Korean Wood Science and Technology 44(5): 685-694

Han, S.Y., Park, C.W., Kim, N.H., Lee, S.H. 2017. Co-solvent system of [EMIM] Ac and DMF to improve the enzymatic saccharification of pussy willow (Salix gracilistyla Miq.). Holzforschung 71(1): 43-50.

Hidayat, W., Qi, Y., Jang, J.H., Febrianto, F., Lee, S.H., Kim, N.H. 2016. Effect of treatment duration and clamping on the properties of heat-treated okan wood. BioResources 11(4): 10070-10086.

Hidayat, W., Qi, Y., Jang, J.H., Park, B.H., Banuwa, I.S., Febrianto, F., Kim, N.H. 2017. Color change and consumer preferences towards color of heat-treated korean white pine and royal paulownia woods. Journal of the Korean Wood Science and
Technology 45(2): 213-222.

Isogai. A. 2008. Advanced Technologies of Cellulose Utilizaton, cmcbooks, 298-309.

Jang, J.H., Kwon, G.J., Kim, J.H., Kwon, S.M., Yoon, S.L., Kim, N.H. 2012. Preparation of cellulose nanofibers from domestic plantation resources. Journal of the Korean Wood Science and Technology 40(3): 156-163.

Jang, J.H., Lee, S.H., Endo, T., Kim, N.H. 2013. Characteristics of microfibrillated cellulosic fibers and paper sheets from Korean white pine. Wood Science and Technology 47(5): 925-937.

Jang, J.H., Lee, S.H., Kim, N.H. 2014. Effect of pMDI as coupling agent on the properties of microfibrillated cellulose-reinforced PBS nanocomposite. Journal of the Korean Wood Sciences and Technology 42(4): 483-490.

Jang, J.H., Lee, M., Kang, E.C., Lee, S.M. 2017. Characteristics of Low Density Fiberboards Bonded with Different Adhesives for Thermal Insulation (II)- Formaldehyde-Total Volatile Organic Compounds Emission Properties and Combustion Shapes. Journal of the Korean Wood Science and Technology 45(5): 580-587.

Jiang, J., Lu, J., Zhou, Y., Huang, R., Zhao, Y., Jiang, J. 2014. Optimization of processing variables during heat treatment of oak (Quercus mongolica) wood. Wood Science and Technology 48(2): 253-267.

Kim, Y.K., Kwon, G.J., Kim, A.R., Lee, H.S. 2018. Effects of Heat Treatment on the Characteristics of Royal Paulownia (Paulownia tomentosa (Thunb.) Steud.) Wood

Grown in Korea. Journal of the Korean Wood Science and Technology 46(5): 511-526.

Kim, Y.S. 2016. Research Trend of The Heat-Treatment of Wood for Improvement of Dimensional Stability and Resistance to Biological Degradation. Journal of the Korean Wood Science and Technology 44(3): 457-476. 
Lee, D., Kim, B.J. 2016. A Study on The Thermal Properties and Activation Energy of Rapidly Torrefied Oak Wood Powder using Non-isothermal Thermogravimetric Analysis. Journal of the Korean Wood Science and Technology 44(1): 96-105.

Lee, S.H., Chang, F., Inoue, S., Endo, T. 2010. Increase in enzyme accessibility by generation of nanospace in cell wall supramolecular structure. Bioresources Technology 101(19): 7218-7223.

Martinka, J., Hroncová, E., Chrebet, T., Balog, K. 2014. The influence of spruce wood heat treatment on its thermal stability and burning process. European Journal of Wood and Wood Products 72(4): 477-486.

Park, Y., Han, Y., Park, J.H., Chang, Y.S., Yang, S.Y., Chung, H. Yeo, H. 2015. Evaluation of physicomechanical properties and durability of Larix kaempferi wood heat-treated by hot air. Journal of the Korean Wood Science and Technology 43(3): 334-343.

Park, Y.G,, Han, Y.J.,. Park, J.H,, Chung, H.W., Kim, H.B,, Yang, S.Y., Chang, Y.A., Yeo, H.Y. 2018. Evaluation of Deterioration of Larix kaempferi Wood Heat-treated by Superheated Steam through Field Decay Test for 12 Months. Journal of the Korean Wood Science and Technology 46(5): 497-510.

Sandberg, D., Kutnar, A. 2015. Recent development of thermal wood treatments: Relationship between modification processing, product properties, and the associated environmental impacts. Wood Science and Technology, pp. 55-59,

Sandberg, D., Haller, P., Navi, P. 2013. Thermo-hydro and thermo-hydro-mechanical wood processing: An opportunity for future environmentally friendly wood products. Wood Material Science \& Engineering 8(1): 64-88.

Scherre, P. 1918. Gottinger Nacher 2: 98.
Segal, L., Creely, J.J., Martin, A.E., Conrad, C.M. 1989. An empirical method for estimating the degree of crystallinity of native cellulose using the $\mathrm{X}$-ray diffractometer. Textile Research Journal 29: 786794.

Seo, P.N., Han, S.Y., Park, C.W., Lee, S.Y., Kim, N.H., Lee, S.H. 2018. Effect of Alkaline Peroxide Treatment on the Chemical Compositions and Characteristics of Lignocellulosic Nanofibrils. BioResources 14(1): 193-206.

Stenudd, S. 2004. Color response in silver birch during kiln-drying. Forest Products Journal 54(6).

Tu, D., Liao, L., Yun, H., Zhou, Q., Cao, X., Huang, J. 2014. Effects of Heat Treatment on the Machining Properties of Eucalyptus urophylla× E. camaldulensis. BioResources 9(2): 2847-2855.

Výbohová, E., Kučerová, V., Andor, T., Balážová, Ž., Vel'ková, V. 2018. The Effect of Heat Treatment on the Chemical Composition of Ash Wood. BioResources 13(4): 8394-8408.

Wang, J., Zheng, Y., Wang, A. 2012. Effect of kapok fiber treated with various solvents on oil absorbency. Industrial Crops and Products 40: 178-184. Wang, X., Wu, Z., Fang, L., Wei, P., Fei, B., Liu, J. 2015. Changes of chemical composition, crystallinity, and fourier transform infrared spectra of eucalypt pellita wood under different vacuum heat treatment temperatures. Forest Products Journal 65(7): 346-351.

Won, K.R., Hong, N.E., Jung, S.Y., Kim, B.R., Byeon, H.S. 2017. Evaluation of Two Species of Soft Wood Decay Resistance for Heat-Treated Wood Using the Catalyst $\left(\mathrm{H}_{2} \mathrm{SO}_{4}\right)$. Journal of the Korean Wood Science and Technology 45(2): 195-201.

Yun, H., Tu, D., Li, K., Huang, J., Ou, L. 2015. Variation and Correlation of Heat-Treated Wood's Crystalline Structure and Impact Toughness. BioResources 10(1): 1487-1494. 


\title{
APPENDIX
}

\author{
(Korean Version)
}

\section{입자크기 및 열처리가 목재 셀룰로오스의 결정 특성에 미치는 영향}

초록 : 본 연구에서는 목분입자 크기 및 열처리가 목재 셀룰로오스의 결정 특성에 미치는 영향을 검토하기 위하여 형태학적 특성, 셀룰로오스 결정특성, 화학성분분석을 실시하였다. 목분의 색은 열처리 온도가 $100^{\circ} \mathrm{C}$ 에서 $200^{\circ} \mathrm{C}$ 로 높아짐에 따라, 진한 황색에서 진한 갈색을 보였다. 열처리 목재셀룰로오스의 상대결정화도는 목재칲에서 200 mesh로 목재의 입자 크기가 작아질수 록 낮은 값을 보였으며, 결정폭의 변화는 거의 없었다. 온도가 $100^{\circ} \mathrm{C}$ 에서 $200^{\circ} \mathrm{C}$ 로 증가함에 따라 목재의 상대결정화도가 증가하 였고, 결정 폭의 변화는 뚜렷하지 않았다. FT-IR분석 결과, 열처리 온도가 높아짐에 따라 - OH 신축에서 피크가 점차 감소한 것을 확인하였다. $1425 \mathrm{~cm}^{-1}$ 의 리그닌 C-H 굽힘과, $1370 \mathrm{~cm}^{-1}$ 의 헤미셀룰로오스 C-H 굽힘은 열처리 온도의 증가에 따른 차이를 보기 어려웠다. $1235 \mathrm{~cm}^{-1}$ 의 OH-phenolic 신축의 특성 피크와 $1031 \mathrm{~cm}^{-1}$ 부근의 탄수화물의 C-C 신축이 열처리 온도가 높아질수록 감소한 것을 확인할 수 있었다. 결론적으로 목재의 입자크기 및 열처리는 목재 셀룰로오스의 결정특성 변화에 영향을 주는 것이 확인되었다.

\section{1. 서 론}

전 세계적으로 지속가능한 환경보존에 대한 요구가 증가하고, 자원과 에너지 부족 현상에 직면하면서 독성의 잔유물이 없고 내후성을 지닌 친환경적인 열처리 목재가 각광받고 있다 (Sandberg et al., 2013, 2015; Esteves et al., 2009). 목재의 열처리는 고온가열로 목재성분의 열분해 수준을 조절하면서 화학적 성분 변화를 유도하여 치수안정성 및 내후성 증대 등을 목표로 하는 가공방법이다(Kim, 2016). 열처리에 의한 목재의 특성 변화에 관한 연구는 다수 보고되어 왔다(Čermák and Dejmal, 2013; Tu et al., 2014; Park et al., 2015; Chung et al., 2016; Gong et al., 2016; Hidayat et al., 2016; Lee and Kim, 2016; Jang et al., 2017; Hidayat et al., 2016; Won et al., 2017; Park et al., 2018). 목재를 열처리하면 추출물이 제거되고, 헤미셀룰로오스가 분해되며 셀룰로오스와 리그닌의 변화가 일어나는데, 열처리에 의한 목재의 재색변화는 헤미셀룰로오스의 감소에 의한 것으로 추정된다(Kim, 2016; Garrote et al., 1999). 열처리에 의해, 목재내의 헤미셀룰로오스가 부분적으로 분해되며, 추출성분을 변화시 키고 새로운 화학 결합을 발생시킨다(Yun et al., 2015). 아세틸기는 열적으로 불안정하며 아세트산을 형성하도록하고, 이 아세트 산은 헤미셀룰로오스의 열분해에 상당한 영향을 준다(Výbohová et al., 2018). 헤미셀룰로오스의 양과 구조의 변화는 휨강도와 인장강도를 감소시키며, 셀룰로오스의 분해는 인장 강도의 감소의 주요 원인으로 생각되어진다(Boonstra et al., 2007). Martinka et al. (2014)은 가문비나무의 열처리 시, 열방출율 감소가 최대로 나타나서 화재가 발생했을 때, 비열처리재보다 열처리재가 더 안전하다고 하였다. 목재를 열처리 하면 재색이 짙게 변하는데, 일반적으로 목재는 $70^{\circ} \mathrm{C}$ 이상의 온도에 노출될 경우 재색 변화가 관찰되며 온도와 습도가 높고 시간이 증가할수록 재색이 짙어진다(Stenudd, 2004). 열처리는 목재셀룰로오스의 결정성을 증가시키며(Bhuiyan et al., 2000), 열처리 온도가 $80^{\circ} \mathrm{C}$ 에서 $200^{\circ} \mathrm{C}$ 까지 증가할 때, 목재의 상대결정화도가 증가한다고 보고하고 있다(Wang et al., 2015). Akgül et al. (2007)은 소나무와 전나무를 이용하여, 일정 시간 동안 열처리 시 상대결정화도가 증가하며, 이는 열처리 시 상대적으로 구성비율이 높은 단사정계 구조가 삼사정계 구조로 변화하기 때문이라고 보고하고 있다.

한편, 목분입자 크기가 감소함에 따라 상대결정화도나 결정크기가 감소되고, 볼밀링에 의해 결정영영이 비결정영역으로 변화하는 것이 보고되고 있다(Isogai, 2008). 최근 목재를 이용한 나노셀룰로오스에 대한 관심이 증대하고 있는데, 나노셀룰로오 스의 제조를 위해선 디스크 밀링으로 입자크기를 감소시키는 것이 필수적이다. 최근 국내 연구에서도 나노셀룰로오스의 제조를 위한 목재의 미립자화는 여러 연구에서 시행되고 있다(Lee et al., 2010; Jang et al., 2012, 2013, 2014; Han et al., 2017; Seo et al., 2018).

따라서 본 연구에서는 목재의 구성 성분 중 가장 많은 비율을 차지하는 셀룰로오스의 활용방안에 앞서 목재의 물리적 특성을 향상시키는 방법인 열처리 가공을 이용하였다. 또한, 목분입자 크기와 열처리가 목재 셀룰로오스의 결정특성에 미치는 영향에 대하여 조사하여 열처리 과정에서 셀룰로오스 결정의 거동에 관한 기초 데이터를 제공하고자 하였다. 


\section{2. 재료 및 방법}

\section{1. 공시재료}

본 연구에서는 강원대학교 학술림에서 자생하는 참오동나무(Paulownia tomentosa)의 가지재를 공시재료로 사용하였다.

\section{2. 실험방법}

2.2.1. 목분 제조

목분의 제조는 강원대학교 산림환경과학대학 공작실에 설치되어 있는 Hammer mill(Hammer Mill Vertica DFZK (GM), buhlergroup Germany) (Fig. 1)을 이용하여 1차 분쇄를 실시하였다. 그리고 연속식 분쇄기(연속식 분쇄기, KOREAMEDI CO., LTD. ,Korea) (Fig. 1)로 목분의 크기를 균일하게 만들어주었으며 40,60, 100mesh 그리고 200mesh 체로 목분입자 크기에 따라 분리하였다.

\subsection{2. 열처리}

강원대학교 공작실에 위치하고 있는 전기로를 사용하여 $6^{\circ} \mathrm{C} / \mathrm{min}$ 로 승온하였고, 목표온도 $100^{\circ} \mathrm{C}$ 와 $200^{\circ} \mathrm{C}$ 에서 30 분간 열처리 를 실시하였다. 이때, 질소가스를 주입한 시료와 질소가스를 주입하지 않은 시료의 중량 감소율을 비교하여, 중량감소율의 차이가 크지 않은 것을 확인하여 질소를 주입하지 않고 열처리한 시료를 사용하였다(Table 1). 이때 목재의 추출성분 및 휘발분이 열처리에 의해 감소된 것이 중량감소의 원인으로 사료된다.

\subsection{3. 형태학적 특성 관찰}

각 처리별 목분의 입자를 관찰하기 위하여 광학현미경(Nikon ECLIPSE, E600)과 이미지 분석 프로그램(IMT I-Solution lite)을 사용하였다.

\subsection{4. 셀룰로오스 결정특성 분석}

X선회절장치(DMAX2100V, Rigaku, Japan)를 이용하여, $40 \mathrm{kV}, 30 \mathrm{~mA}$ 조건하에서 각 조건에서 처리한 목분의 X선회절강 도곡선을 얻었다. 다음과 같은 Segal법(Segal et al, 1959) 과 Scherrer(Scherrer, 1918)식에 의거하여 상대결정화도와 결정폭을 각각 계산하였다.

Segal법에 의한 상대결정화도

$$
\begin{aligned}
& C r .(\%)=\frac{I_{200}-I_{a m}}{I_{200}} \times 100 \\
& I_{200}:(200) \text { 의 회절강도 }\left(2 \Theta=22.8^{\circ}\right) \quad I_{a m} \text { : 비결정부분의 회절강도 }\left(2 \Theta=18^{\circ}\right)
\end{aligned}
$$

Scherrer식에 의한 결정폭

$$
L(h k l)=\frac{K \cdot \lambda}{\beta \cdot \cos \theta}
$$

$\mathrm{L}$ : 결정 폭, $\mathrm{K}:$ Scherrer 상수 $0.9, \lambda: \mathrm{X}$ 선의 파장 $(\lambda=0.1542 \mathrm{~nm}), \beta$ : 반치폭(라디안), $\theta: \operatorname{Bragg}$ 각도

\subsection{5. 화학성분분석}

목분을 열처리 후 화학성분변화를 조사하기 위하여 강원대학교 공동실험실습관에 있는 FT-IR spectrometer (PerkinElmer Inc., USA)를 이용하여, Attenuated Total Reflection spectroscopy법으로 400 4000 cm- 1 의 범위에서 측정하였다. 시료는 미처리 시료와 $100^{\circ} \mathrm{C}, 200^{\circ} \mathrm{C}$ 에서 열처리한 참오동나무 가지재의 $100 \mathrm{mesh}$ 목분을 사용하였다.

\section{3. 결과 및 고찰}

\section{1. 열처리 목분의 육안적 색변화}

Fig. 2는 처리 온도에 따른 입자 별 목재 셀룰로오스를 육안으로 관찰한 사진이다. 비열처리 목분은 옅은 담갈색이었고, 열처리에 의하여 진한 황색에서 진한 고동색으로 변하였다.

\section{2. 열처리 목분의 형태학적 특성}

Fig. 3은 열처리 온도 조건에 따른 입자 별 목분을 광학현미경을 통하여 관찰한 사진이다. 열처리 온도가 높아질수록 진한 갈색으로 변화하였다. Garrote et al. (1999)은 열처리에 의한 목재의 재색변화를 연구하여 열처리에 의한 색변화는 헤미셀룰로오 
스의 감소에 의한 것으로 보고하였다. Výbohová et al. (2018)은 물푸레나무를 이용하여 열처리 목재를 연구하였는데, $160^{\circ} \mathrm{C}$ 에 서 산화가 시작되어 새로운 카르보닐기와 카르복실기가 생성되고, $180^{\circ} \mathrm{C}$ 에서부터 리그닌 양이 증가하면서 색 변화에 기여했다 고 보고하였다.

\section{3. 열처리 목재셀룰로오스의 결정특성}

Fig. 4는 각각 다른 입자크기의 목분들의 X선회절강도곡선으로 전형적인 셀룰로오스 I의 구조를 나타내고 있다. 목분입자 크기가 작아질수록 (1) $\overline{1} 0),(110)$, 및 (200)면의 피크가 감소하는 경향이 있었다. Table 2 는 X선회절강도곡선에서 계산한 상대결 정화도와 결정폭의 결과이다. 목재칲의 상대결정화도가 가장 크게 나타났고, 200mesh 시료의 상대결정화도가 가장 낮았다. 또한 control 시료의 상대결정화도보다 $100^{\circ} \mathrm{C}$ 에서 열처리한 것이, $100^{\circ} \mathrm{C}$ 보다 $200^{\circ} \mathrm{C}$ 에서 열처리한 시료의 상대결정화도 값이 컸다. 목분입자 크기가 작을수록 상대결정화도가 낮아지고, 또한 열처리 온도가 증가함에 따라 목재의 상대결정화도가 증가하고, 결정폭의 변화는 거의 없는 것을 명확히 알 수 있었다.

Bhuiyan et al. (2000)은 가문비나무와 너도밤나무의 목분을 이용해서 열처리가 목재셀룰로오스의 결정화도를 상당히 증가시 킨다고 하였고, Wang et al. (2015)은 유칼립투스재를 재료로, 열처리 온도가 $80^{\circ} \mathrm{C}$ 에서 $200^{\circ} \mathrm{C}$ 까지 증가할 때, 목재의 상대결정화 도가 증가한다고 보고하였다. Kim et al. (2018)은 참오동나무 열처리재의 연구에서 열처리에 의해 오동나무재의 상대결정화도가 증가한다고 보고하고 있어 본 연구의 결과와 일치하는 것으로 생각된다. 또한, Akgül et al. (2007)은 열처리 온도뿐만 아니라 열처리 시간이 결정화도의 변화에 변화를 준다고 하였다. 한편, Yun et al. (2015)은 유칼립투스 수종으로 열처리를 실시하면 결정영역의 변화가 뚜렷하지 않으나, 결정 길이와 폭의 경우 온도가 증가함에 따라 증가한다고 하여, 본 연구의 결과와 상이하였다. 결정의 길이 및 폭에 관한 열처리 효과는 금후 더욱 검토가 필요하다고 생각된다. 열처리 온도의 증가에 따른 상대결정화도의 증가는 목재 구성성분 중 추출성분과 휘발분등이 열처리에 의하여 감소되어 강도적 성능이 증가하는 것 뿐만아니라 비결정 영역이 파괴되어 결정영역의 비율이 증가하여 열처리가 결정특성에 긍정적 영향을 미치는 것으로 사료된다.

\section{4. 화학성분 분석}

열처리 온도에 의한 목재의 화학성분변화를 조사하기 위하여 FT-IR 분석을 실시하였다. 비열처리 시료와 $100^{\circ} \mathrm{C}, 200^{\circ} \mathrm{C}$ 의 온도로 열처리한 시료의 FT-IR 스펙트럼은 Fig. 6과 같다. Table 3은 Fig. 6의 스펙트럼을 토대의 분석한 표로서 여러 연구 (Bodirlau et al., 2009; Dai et al., 2011; Wang et al., 2012)에서 추출한 Table 4를 참고로 하였다. $3339 \mathrm{~cm}^{-1}$ 에서 -OH 신축, $2917 \mathrm{~cm}^{-1}$ 에서 표면 왁스에 해당되는 C-H 진동, $1735 \mathrm{~cm}^{-1}$ 에서 카르보닐기의 C=0 신축, $1425 \mathrm{~cm}^{-1}$ 에서 리그닌의 C-H 굽힘, $1370 \mathrm{~cm}^{-1}$ 에서 헤미셀룰로오스의 C-H 굽힘, $1235 \mathrm{~cm}^{-1}$ 에서 OH-phenolic 신축의 특성 피크, $1031 \mathrm{~cm}^{-1}$ 부근에서 탄수화물의 C-C 신축의 특성 피크를 확인할 수 있었다.

이때 열처리 온도가 높아짐에 따라 $3339 \mathrm{~cm}^{-1}$ 부근의 $-\mathrm{OH}$ 신축의 피크, $1235 \mathrm{~cm}^{-1}$ 의 OH-phenolic 신축의 특성 피크 그리고 $1031 \mathrm{~cm}^{-1}$ 부근의 탄수화물의 C-C 신축이 점차 감소한 것을 확인하였다. 이는 열처리에 의해 수산기그룹의 감소와 함께 탈수 반응이 일어나고 목분시료 중에 탄수화물이 감소하여 초래된 것으로 사료된다. 또한 $1735 \mathrm{~cm}^{-1}$ 에서 카르보닐기의 $\mathrm{C}=0$ 신축은 열처리 온도에 의한 변화가 뚜렷하지 않아 Výbohová et al. (2018)의 연구와 상반되는 결과를 나타냈다. 이는 온도 조건의 범위가 세부적이지 않아 명확한 결과를 나타내지 않기 때문으로 사료된다. 리그닌 C-H 굽힘과, $1370 \mathrm{~cm}^{-1}$ 의 헤미셀룰로오스 C-H 굽힘은 열처리 온도의 증가에 따른 차이를 보기 어려웠다. 열처리에 의하여 헤미셀룰로오스, 리그닌의 변화가 예상되었으나 본 결과에서는 그런 경향이 적게 나타났다.

\section{4. 결 론}

열처리 및 입자 크기에 따른 목재 셀룰로오스의 결정 특성을 조사한 결과는 다음과 같다.

1. 목분의 색은 열처리 온도가 $100^{\circ} \mathrm{C}$ 에서 $200^{\circ} \mathrm{C}$ 로 증가함에 따라 연한 황색에서 진한 황색혹은 진한 갈색으로 변화하였다.

2. 열처리 목재 셀룰로오스의 결정화도는 목재의 입자크기가 작아질수록 상대결정화도가 감소하는 경향을 보였고, 결정폭의 변화는 거의 없었다.

3. 열처리 온도가 증가함에 따라 목재의 상대결정화도는 증가하였고, 결정폭은 변화하지 않았다.

4. FT-IR분석 결과, $3339 \mathrm{~cm}^{-1}$ 에서 -OH 신축, $2917 \mathrm{~cm}^{-1}$ 에서 표면 왁스에 해당되는 C-H 진동, $1735 \mathrm{~cm}^{-1}$ 에서 카르보닐기 의 C=0 신축, $1425 \mathrm{~cm}^{-1}$ 에서 리그닌의 C-H 굽힘, $1370 \mathrm{~cm}^{-1}$ 에서 헤미셀룰로오스의 C-H 굽힘, $1235 \mathrm{~cm}^{-1}$ 에서 $\mathrm{OH}-$ phenolic 신축의 특성 피크, $1031 \mathrm{~cm}^{-1}$ 부근에서 탄수화물의 C-C 신축의 특성 피크를 확인할 수 있었다. 